Lepr Rev (1986) 57, Supplement 3, 127-133

\title{
The future of leprosy in the Dominican Republic: experience with multidrug therapy
}

\author{
DENIS MARTINEZ CRUZ \\ Instituto Dermatologico, Apartado 1090, Santa Domingo, \\ Dominican Republic
}

\section{Leprosy in the Dominican Republic}

The history of leprosy in our country begins in the colonial days, even though many authors have tried to demonstrate that this illness existed among the natives. These theories have been refuted, as for instance, by Charlevoix in his book 'History of the Island', where he refers to leprosy as an illness 'only found in the city'. In other words, his remark suggests that leprosy did not exist in the island generally before colonial development.

Checking the chronicles, we found that in 1581 the 'San Lazaro Hospital' existed, built in agreement with Indian Laws.

In 1844 with our national independence, laws were made so that all persons with leprosy had to be sent to a hospital and isolated. This was the first legal decree about the disease in our country.

In 1922 the 'National Colony for Leprosy' was founded, the patients were attended by the congregation of 'Sisters Mercedarias' and the lepers were kept there until 1981 when they were taken to an asylum in a new building, where old people and invalids now live. By the end of 1965 there were 776 lepers registered; $414(53 \%)$ of them had 'malign forms' of leprosy and $362(47 \%)$ 'benign forms'.

Dr Huberto Bogaert and four assistant doctors, after gaining experience from other countries, started work in the Dermatological Institute in February 1966 with an aggressive campaign against leprosy. He initiated the programme of leprosy control which continues in the Dominican Republic today.

During the period 1966-72 a study was set up of the leprosy problem in the Dominican Republic and the resources needed for a control programme were defined. In this period treatment was limited to the use of oral sulphones and clofazimine for those suspected of resistance to the former. In 1972 an agreement of coordination was signed between the Dermatological Institute and the State Secretary of Public Health, giving to the Institute the responsibility of programming, directing and executing the programme all over the National territory. 
The new programme of leprosy control in 1973-77 established ambulatory treatment based on oral or injected sulphones. Clofazimine was given for cases clinically sulphone-resistant and rifampicin was also used for some cases.

In the period 1978-82, the therapeutic regimens followed guidelines of the PAS/WHO and regional advisors. Some of their objectives were the reduction of endemic leprosy with the diminution of the rates of incidence and prevalence, constant vigilance of Mitsuda-negative cases, active search of new cases, education of the community, etc. Therapeutic changes were then introduced, e.g. the use of rifampicin, $600 \mathrm{mg}$ daily, and clofazimine, $100 \mathrm{mg}$ daily, with a weekly checking of all cases with positive bacteriology for 2 months, and then continued with oral/or injected sulphone.

The programme for 1983-87 has, as its principal purpose, the reduction of leprosy in our country by the diminution of incidence and prevalence rates with integrated treatment for known patients and active new case detection. This programme includes the treatment with multidrugs of all cases of leprosy, and the revison of our recording systems with the introduction of the OMSLEP System. We intend to emphasize health education, early diagnosis and early treatment of all cases with multidrugs.

Based on available data in our information systems the following results have been obtained in the last 20 years:

The rate of new MB cases, related to the total of the new cases, was higher in 1978 with $0 \cdot 78$, declining slowly to 0.37 in 1985 .

The rate of new cases from dermatological consultation has remained between 0.67 for 1979 and 0.54 for 1985 . But we noticed that the yield of cases for every 1000 dermatological consultations has declined from 6.91 in 1974 to 0.54 in 1985.

The rate of new cases discovered in domicilliary contacts increased from $0 \cdot 17$ in 1974 to 0.26 in 1985 , but the yield of case-finding for every 1000 examined contacts has reduced from 16.70 in 1974 to 6.03 for 1985 .

The rate of newly discovered cases has remained between 0.08 for 1981 and 0.05 for 1985 ; but the yield for every 1000 patients has declined from $4 \cdot 13$ cases in 1974 to 0.73 in 1985.

The rate of new cases discovered by population surveys has diminished from $0 \cdot 23$ (1975) when the provinces with highest prevalence were examined, to 0.01 (1983). The yield for every 1000 persons declined from $9 \cdot 94$ cases (1973) to $0 \cdot 10$ (1985).

The rate of new cases with physical deformity (of $2 \mathrm{nd}$ and 3 rd grade) has diminished from 0.30 in 1978 to 0.06 in 1985.

The rate of bacteriologically positive cases increasd from $0 \cdot 18$ in 1973 to $0 \cdot 27$ in 1985. This was due, at least in part, to improvement in our methodology and techniques in the taking of skin smears.

The rate of treatment non-compliance to treatment increased from 0.01 (1966) to 0.05 (1985), the pigmentation caused by clofazimine being the principal cause of treatment rejection. 
The rate of leprosy reaction in multidrug cases diminished gradually from $0 \cdot 31$ in 1973 to $0 \cdot 02$ and has remained at that level since 1983 .

The rate of the number of cases achieving bacterial negativity during the year, compared with those who started the year with positive bacteriology, increased from 0.08 in 1974 to 0.58 in 1985 .

The rate of new cases in patients under 15 years was $0 \cdot 13$ in 1966. Subsequently there are two rises: in 1975 it went to 0.28 and in 1984 to $0 \cdot 31$. The incidence in this age group started with 2.03 for 1966 , rose slowly to 5.64 in 1975 , later dropping to 1.99 in 1985.

The incidence for all ages was higher in 1975 when it rose to $10 \cdot 36$, declining slowly until 4.38 in 1985 . The prevalence rate also declined from 0.92 in 1980 to 0.67 in 1985 .

Generally speaking there is evidence of earlier detection of new cases and an improvement in incidence and prevalence, with greater efficiency in our use of chemotherapy. With sustained effort we hope to achieve control and eventually eradication.

\section{Experience in multidrug therapy}

Since the Leprosy Control Programme started in 1966 in the Dominican Republic, until today, treatment has been changing from oral or injected monotherapy, or both, to non-supervised multidrugs for short periods, and finally to supervised multidrug therapy, starting in 1983 , following the advice of the OMS Group of Experts. But we have made some modifications, mainly due to the fact that our programme is directed by a private, philanthropic institution. Our multibacillary cases receive supervised rifampicin $600 \mathrm{mg}$ and clofazimine $300 \mathrm{mg}$, each month. Also self-administered clofazimine $300 \mathrm{mg}$ and dapsone 600 mg each week. This treatment will be used for a minimum of 3 years.

The paucibacillary cases receive supervised rifampicin $600 \mathrm{mg}$ and clofazimine $300 \mathrm{mg}$ each month; and self-administrated dapsone $600 \mathrm{mg}$ each week.

The monthly treatment is given by the country auxiliaries, in dermatology centres as well as in patients' homes, but the medical supervision is by the dermatoleprologist, who also carries out the patient re-examination every 6 months.

A review of our patients with MDT treatment shows the following results: From 4028 patients who received MDT in 12 regular doses or more, $9 \cdot 2 \%$ were children of less than 15 years old and $90 \cdot 8 \%$ were patients older than 15 . Sixtytwo per cent were paucibacillary forms of leprosy (Table 1).

Eighty-two per cent of the patients treated with MDT had previously received oral dapsone treatment, injectable dapsone, clofazimine and/or non-supervised rifampicin. The time of previous treatment ranged from 2 months to 15 years (Table 2). 
Table 1. Number of cases in MDT, by age, sex and clinical group.

\begin{tabular}{|c|c|c|c|c|c|c|}
\hline \multirow{3}{*}{$\begin{array}{l}\text { Clinical } \\
\text { group }\end{array}$} & \multicolumn{6}{|c|}{ Age and sex } \\
\hline & \multicolumn{2}{|c|}{$0-14$ years } & \multicolumn{2}{|c|}{15 years and more } & \multicolumn{2}{|c|}{ Total } \\
\hline & Males & Females & Males & Females & No. & $\%$ \\
\hline MB & 31 & 16 & 976 & 517 & 1540 & 38 \\
\hline PB & 171 & 154 & 891 & 1272 & 2488 & 62 \\
\hline Total & 202 & 170 & 1867 & 1789 & 4028 & 100 \\
\hline$\%$ & $5 \cdot 0$ & $4 \cdot 2$ & $46 \cdot 4$ & $44 \cdot 4$ & $100 \cdot 0$ & 一 \\
\hline
\end{tabular}

Table 2. Number of cases with previous treatment or not, by clinical group.

\begin{tabular}{|c|c|c|c|c|c|c|}
\hline \multirow{3}{*}{$\begin{array}{l}\text { Clinical } \\
\text { group }\end{array}$} & \multicolumn{6}{|c|}{ Treatment } \\
\hline & \multicolumn{2}{|c|}{ Previous } & \multicolumn{2}{|c|}{ MDT only } & \multicolumn{2}{|c|}{ Total } \\
\hline & No. & $\%$ & No. & $\%$ & No. & $\%$ \\
\hline MB & 1211 & $78 \cdot 6$ & 329 & $21 \cdot 4$ & 1540 & $100 \cdot 0$ \\
\hline PB & 2087 & 83.9 & 401 & $16 \cdot 1$ & 2488 & $100 \cdot 0$ \\
\hline Total & 3298 & $100 \cdot 0$ & 730 & $100 \cdot 0$ & 4028 & $100 \cdot 0$ \\
\hline$\%$ & $81 \cdot 9$ & - & $18 \cdot 1$ & - & $100 \cdot 0$ & - \\
\hline
\end{tabular}

Table 3. Patients with treatment previous to MDT, with or without injuries.

\begin{tabular}{|c|c|c|c|c|c|}
\hline \multirow[b]{3}{*}{ Situation } & \multicolumn{5}{|c|}{ With injuries } \\
\hline & \multirow{2}{*}{$\begin{array}{l}\text { Clinical } \\
\text { group }\end{array}$} & \multicolumn{2}{|c|}{ Clinical } & \multicolumn{2}{|c|}{ Bacteriological } \\
\hline & & No. & $\%$ & No. & $\%$ \\
\hline \multirow[t]{3}{*}{ Cases with injuries cured with MDT } & MB & 353 & $38 \cdot 5$ & 121 & $78 \cdot 1$ \\
\hline & PB & 462 & $50 \cdot 4$ & - & - \\
\hline & Subtotal & 815 & $88 \cdot 9$ & 121 & $78 \cdot 1$ \\
\hline Did not cure & & 101 & $11 \cdot 1$ & 34 & $21 \cdot 9$ \\
\hline Total with injuries & & 916 & $100 \cdot 0$ & 155 & $100 \cdot 0$ \\
\hline
\end{tabular}


There were 916 previously treated patients with clinical lesions when they started MDT. Three hundred and fifty-three MB cases (38.5\%) and $462 \mathrm{~PB}$ cases $(50 \cdot 4 \%)$ were cured. In 101 cases $(11 \cdot 1 \%)$ the treatment was ineffective. In the patients with positive bacteriology, 121 cases $(78.1 \%)$ became negative and $21.9 \%$ stayed positive (Table 3 ).

From the patients treated only with MDT, 656 had clinical lesions which disappeared in $109 \mathrm{MB}$ cases (16.6\%) and $323 \mathrm{~PB}$ cases (49.2\%); in 224 cases

Table 4. Patients that received only MDT, with or without injuries.

\begin{tabular}{|c|c|c|c|c|c|}
\hline \multirow[b]{3}{*}{ Situation } & \multicolumn{5}{|c|}{ With injuries } \\
\hline & \multirow{2}{*}{$\begin{array}{c}\text { Clinical } \\
\text { group }\end{array}$} & \multicolumn{2}{|c|}{ Clinical } & \multicolumn{2}{|c|}{ Bacteriological } \\
\hline & & No. & $\%$ & No. & $\%$ \\
\hline \multirow[t]{3}{*}{ Cases with injuries cured with MDT } & MB & 109 & $16 \cdot 6$ & 74 & $53 \cdot 2$ \\
\hline & PB & 323 & $49 \cdot 2$ & - & - \\
\hline & Subtotal & 432 & $65 \cdot 8$ & 74 & $53 \cdot 2$ \\
\hline Did not cure & & 224 & $34 \cdot 2$ & 65 & $46 \cdot 8$ \\
\hline Total with injuries & & 656 & $100 \cdot 0$ & 139 & $100 \cdot 0$ \\
\hline
\end{tabular}

Table 5. MB cases with treatment previous to MDT that inactivated clinically or bacteriologically, by number of months between the start of the MDT and the inactivation.

\begin{tabular}{crrrrr}
\hline & \multicolumn{2}{c}{ Clinical cure } & & \multicolumn{2}{c}{ Bacteriological cure } \\
\cline { 2 - 3 } \cline { 5 - 6 } $\begin{array}{c}\text { No. of months } \\
\text { MDT }\end{array}$ & No. & $\%$ & & No. & $\%$ \\
\hline $1-4$ & 5 & $1 \cdot 5$ & & - & - \\
$5-8$ & 77 & $21 \cdot 8$ & & 28 & $23 \cdot 1$ \\
$9-12$ & 68 & $19 \cdot 3$ & & 19 & $15 \cdot 7$ \\
$13-16$ & 48 & $13 \cdot 6$ & & 24 & $19 \cdot 8$ \\
$17-20$ & 52 & $14 \cdot 7$ & & 19 & $15 \cdot 7$ \\
$21-28$ & 66 & $18 \cdot 7$ & & 21 & $17 \cdot 4$ \\
$29-36$ & 34 & $9 \cdot 6$ & & 9 & $7 \cdot 4$ \\
Ignored & 3 & $0 \cdot 8$ & & 1 & $0 \cdot 8$ \\
\hline Totals & 353 & $100 \cdot 0$ & & 121 & $100 \cdot 0$ \\
\hline
\end{tabular}


(34.2\%) lesions persisted. The bacilloscopy was negative in $74 \mathrm{MB}$ cases $(53 \cdot 2 \%)$ and positive in $46.8 \%$ (Table 4 ).

Of the $353 \mathrm{MB}$ cases with clinical lesions who had received treatment prior to the use of MDT, these lesions disappeared in $42.6 \%$ between 1 and 12 months of treatment with MDT. In $57 \cdot 4 \%$ they disappeared after 13 to 36 months of MDT. In those who had positive bacteriology, $38.8 \%$ were negative in the first 12 months of treatment with MDT (Table 5).

Table 6. MB cases that inactivated clinically or bacteriologically receiving only MDT, by number of months between the start of the MDT and the inactivation.

\begin{tabular}{cccccc}
\hline & \multicolumn{2}{c}{ Clinical cure } & & \multicolumn{2}{c}{ Bacteriological cure } \\
\cline { 2 - 3 } \cline { 5 - 6 } $\begin{array}{c}\text { No. of months } \\
\text { MDT }\end{array}$ & No. & $\%$ & & No. & $\%$ \\
\hline $1-4$ & - & $0 \cdot 0$ & & 5 & $6 \cdot 7$ \\
$5-8$ & 33 & $30 \cdot 2$ & & 15 & $20 \cdot 3$ \\
$9-12$ & 30 & $27 \cdot 5$ & & 15 & $20 \cdot 3$ \\
$13-16$ & 15 & $13 \cdot 8$ & & 11 & $14 \cdot 9$ \\
$17-20$ & 16 & $14 \cdot 7$ & & 11 & $14 \cdot 9$ \\
$21-28$ & 11 & $10 \cdot 1$ & & 10 & $13 \cdot 5$ \\
$29-36$ & 4 & $3 \cdot 7$ & & 7 & $9 \cdot 4$ \\
Ignored & - & $0 \cdot 0$ & & - & $0 \cdot 0$ \\
\hline Totals & 109 & $100 \cdot 0$ & & 74 & $100 \cdot 0$ \\
\hline
\end{tabular}

Table 7. Number of PB cases that kept clinically or histologically active to the 31.12 .85 by months of MDT

\begin{tabular}{cccccc}
\hline & \multicolumn{3}{c}{ Active } & & \multicolumn{2}{c}{ Total } \\
\cline { 2 - 3 } \cline { 5 - 6 } $\begin{array}{c}\text { No. of MDT } \\
\text { months }\end{array}$ & Clinical & Histopathological & & No. & $\%$ \\
\hline $1-4$ & - & - & & - & - \\
$5-8$ & - & - & & - & - \\
$9-12$ & 20 & 12 & & 32 & $18 \cdot 1$ \\
$13-16$ & 19 & 21 & & 40 & $22 \cdot 6$ \\
$17-20$ & 21 & 22 & & 43 & $24 \cdot 3$ \\
$21-28$ & 27 & 20 & & 47 & $26 \cdot 6$ \\
$29-36$ & 9 & 6 & & 15 & $8 \cdot 5$ \\
Ignored & - & - & & - \\
\hline Totals & 96 & 81 & & 177 & $100 \cdot 0$ \\
$\%$ & $54 \cdot 2$ & $45 \cdot 8$ & $100 \cdot 0$ & - \\
\hline
\end{tabular}


In the $109 \mathrm{MB}$ cases with clinical lesions, treated with MDT only, the injuries disappeared in the first 12 months of treatment with MDT in $57.7 \%$ of the cases. In $42 \cdot 3 \%$ of the cases, the lesions disappeared between 13 and 36 months of receiving the MDT. Of the 74 cases in which the bacteriology was negative, the change to negative occurred in the first 12 months of receiving MDT in $43.3 \%$ of the cases (Table 6).

Of the 2488 paucibacillary cases treated with MDT, 177 cases $(7 \cdot 1 \%)$ appear not to have been cured after receiving from 12 to 36 doses of MDT. Of the 177 cases, $96(54 \cdot 2 \%)$ are not clinically cured and 81 cases $(45 \cdot 8 \%)$ are still active on histopathology. We use histological control in our programme to verify healing in PB cases in which the clinical lesions have disappeared. The $18.1 \%$ of patients apparently not cured received 12 to 36 doses of MDT (Table 7).

Of the paucibacillary cases treated with MDT, 1050 were cured and subsequently discharged in 1985; 1261 remain under observation in 1986 without treatment (Table 8).

At this stage, we are disappointed by clinical and bacteriological results in some of our patients on multidrug therapy, who have failed to show the expected improvement. However, this may be related to individual variations in response to the drugs concerned. We are giving particular attention to the period of treatment required for a successful outcome in multibacillary cases.

Table 8. Number of PB cases without treatment after MDT, by situation, age or sex.

\begin{tabular}{|c|c|c|c|c|c|}
\hline \multirow[b]{3}{*}{ Situation } & \multicolumn{5}{|c|}{ Age and sex } \\
\hline & \multicolumn{2}{|c|}{$0-14$ years } & \multicolumn{2}{|c|}{15 years and more } & \multirow[b]{2}{*}{ Total } \\
\hline & Males & Females & Males & Females & \\
\hline $\begin{array}{l}\text { Observation without treatment } \\
\text { Healing }\end{array}$ & 128 & 123 & 431 & 579 & 1261 \\
\hline discharge & 42 & 45 & 380 & 583 & 1050 \\
\hline Total & 170 & 168 & 811 & 1162 & 2311 \\
\hline
\end{tabular}

